\title{
Syntactic structures of subordinate clauses in English oral and written discourse
}

\author{
[Syntakticke struktury vedlajsích viet $\mathrm{v}$ anglickom hovorenom a \\ pisanom prejave]
}

\author{
Rita Rafajlovicova
}

DOI: 10.18355/XL.2018.11.02.58

\begin{abstract}
The study presents a detailed formal and functional corpus-based analysis of subordinate clauses in different naturally occurring texts of spoken and written discourse. It also investigates the frequency of occurrence of subordinate clauses and the functions they serve within the analysed text types (newspaper, academic prose, fiction, and interview). The results obtained from the analysis show the differences in the use of particular formal and functional types of subordinate clauses as well as in their frequency of occurrence within the analysed media of different level of formality. Besides other findings, the results of the analyses also suggest that the distinctions in the use of subordinating strategies are not influenced by the medium (spoken or written), but they can be attributed to the degree of formality and the discursive function of the text type.
\end{abstract}

Key words: subordination, subordinate clauses, corpus, spoken discourse, written discourse, text type

\begin{abstract}
Anotácia
Práca prezentuje výsledky detailnej formálnej a funkčnej korpusovej analýzy vedl'ajších viet $\mathrm{v}$ rôznych autentických textoch hovoreného a písaného diskurzu. Okrem iného skúma aj frekvenciu používania vedl'ajších viet a funkcie, ktoré zohrávajú v rámci analyzovaných typov textov. Kvantitatívny a kvalitatívny výskum sa zakladá na analýze materiálu získaného z vlastného korpusu anglických textov rôznych štýlov (publicistické texty, odborné texty, umelecké texty, hovorené prejavy). Výsledky získané pomocou analýz textov poukazujú na rozdiely v používaní jednotlivých funkčných a formálnych typov vedl'ajších viet ako aj vo frekvencii ich používania $\mathrm{v}$ spomínaných médiách odlišnej úrovne formálnosti. Popri iných zisteniach, výsledky poukazujú aj na fakt, že používanie rozdielnych subordinačných stratégií nezávisí do takej mieri od toho, či je jazyk hovorený alebo písaný, ale skôr od úrovne formálnosti daného textu.
\end{abstract}

Kl'účové slová: podrad'ovanie, vedl'ajšie vety, písomný prejav, ústny prejav, typ textu

\section{Úvod}

Všeobecná teória gramatickej organizácie prirodzeného jazyka, založená na funkčnom nazeraní na podstatu jazyka, sa nazýva funkčná gramatika. Funkčná gramatika skúma „tvarovanie“ prehovorov v závislosti od ciel’a a účelu používatel’a jazyka. Dik (1978) ju charakterizuje ako „vetnú gramatiku, ktorá je súčast’ou širšej teórie verbálnej interakcie a zároveň subkomponentom modelu systému prirodzeného používania jazyka, pri ktorom sa l’udská lingvistická kapacita spája s epistemickou, logickou, vnemovou a sociálnou kapacitou." (Siewierska, 1991:1). Dôraz sa kladie skôr na vhodnost' použitia formy pre daný komunikatívny účel v danom kontexte, než na vlastnú gramatickú formu. V popredí záujmu sú funkcie jednotlivých štruktúr a ich súčastí a významy kontexte. Pri tomto druhu analýzy jazyka sa používajú dáta získané z autentických textov v špecifických kontextoch. Funkčná analýza však musí 
do určitej miery brat' do úvahy aj formu a formálna analýza zas musí brat' do úvahy aj význam a funkciu.

Pri výskume jazyka ako komunikačného systému sa teda nemôžeme jednoducho obmedzit' iba na formálnu a štrukturálnu charakteristiku jazyka, ale je vel'mi potrebné ozrejmit' to, na čo jednotlivé formy slúžia a ako sa používajú, t.j. ako sa gramatika daného jazyka využíva na zmysluplnú komunikáciu. V súvislosti s tým sa vynára mnoho zaujímavých otázok týkajúcich sa najmä účelu používania jazyka, jeho usporiadania tak, aby umožnil používatel'om vyjadrovat' svoje myšlienky, a menej kompozičného charakteru jazyka. Jednoducho povedané, nie je dôležité iba to čo, povieme, ale aj ako to povieme. Predpokladáme, že variabilita je v lingvistickom prejave determinovaná výberom jazykových prostriedkov používatel'a jazyka (pisatel’a/rečníka) a že tento výber je výsledkom celej škály faktorov, ktoré ho môžu ovplyvnit', ako napr. kontext, účastníci interakcie, účel a príčina interakcie a v neposlednom rade aj to, či je interakcia ústna alebo písomná. Rôzne typy textov produkujú odlišný typ jazyka, kde významný rozdiel medzi formálnym a neformálnym alebo verejným a súkromným diskurzom nie je iba kategoriálnym rozdielom.

\section{Metodologické východiská}

Rôzne aspekty odlišností hovoreného a písaného jazykového prejavu sú predmetom skúmania už od nepamäti. Prvé gramatické analýzy, týkajúce sa komplexnosti viet v anglickom jazyku sa objavili v 20-tych rokoch minulého storočia, ked' Stormzand a O’Shea (1924) skúmali vety napísané det’mi a porovnávali ich s vetami napísanými dospelými v publicistických a umeleckých textoch a súkromnej korešpondencii. Od tých čias sa objavilo nespočetné množstvo štúdií a výskumov, ktoré sa venujú syntaktickej komplexnosti, subordinačným stratégiám a formálnym a funkčným analýzam gramatických štruktúr ústnej a písomnej produkcie. Pokial' niektorí autori komparatívnych štúdií (Harrel 1957, Drieman 1962, Blankenship 1962, O’Donnell 1974, Chafe and Tannen 1987) považujú písaný jazyk za syntakticky komplexnejší než hovorený vd’aka vysokej frekvencii subordinačných štruktúr, iní (Beaman 1984, Halliday 1989, McCarthy 1998, Haiman-Thompson 1988, Carter and McCarthy 2006, and Biber et al. 1999) naopak zistili, že orálna produkcia prezentuje vyššiu frekvenciu subordinácie ako písomná. Dlhotrvajúci názor, že ústny prejav je menej prepracovaný a obsahovo jednoduchší ako písaný, sa na základe výsledkov ich výskumov zmenil a lingvisti dospeli k zisteniu, že ústny prejav má svoju vlastnú kategóriu komplexnosti určenú samotným médiom.

V poslednej dekáde 20.storočia dramaticky vzrástol aj vd’aka novým výskumným technológiám počet analýz písaných textov a hovorených prejavov so zameraním na partikulárne syntaktické štruktúry a výsledky týchto výskumov odhalili množstvo, do tohto času nevysvetlených, gramatických faktov. Záujem lingvistov sa sústredil predovšetkým na zist'ovanie, čo determinuje výber gramatických štruktúr v ústnej a písomnej interakcii. S príchodom korpusovej lingvistiky a narastajúcim počtom výskumov v oblasti hovoreného a písaného diskurzu, sú lingvisti schopní získat' spol'ahlivé a porovnatel'né dáta pre analýzy a poskytnút' reliabilné, efektívne a systematické charakteristiky gramatických vlastností oboch médií, čo je bezpochyby vel'kou výhodou pre d’alší rozvoj v tejto oblasti.

Jedným z najplodnejších lingvistov $\mathrm{v}$ tejto oblasti výskumu je nepochybne Conrad Biber, ktorý poskytol jednotnú lingvistickú analýzu hovorených a písaných jazykových štýlov, použitím kvantitatívnych metód frekvenčnej distribúcie špecifických lingvistických znakov na pozadí ich funkčných charakteristík. Jeho práce sú považované za štartovaciu čiaru vo výskume variácií jazyka. V svojej práci

XLinguae, Volume 11, Issue 2, April 2018, ISSN 1337-8384, eISSN 2453-711X 
Longman Grammar of Spoken and Written English (LGSWE, 1999) poukazuje na rozdielnost' žánrov založenej na distribúcii gramatických štruktúr, prezentuje, ktoré štruktúry, slovesné časy a lexikálne vol’by sa v nich vyskytujú, precízne definuje syntaktické rozdiely medzi žánrami a poskytuje dokonalú charakteristiku súčasného hovoreného a písaného anglického jazyka. K danej problematike nepochybne prispeli svojimi prácami aj d’alší lingvisti začiatkom 21.storočia, ako napr. Cristofaro (2003), ktorá vo svojej publikáciou Subordination sa zaoberá lingvistickou analýzou subordinácie vychádzajúcou z 80 rôznych jazykov. Vo svojej analýze skúma vzt’ahy vedl'ajších viet shlavnými a sústred’uje sa na funkčné korelácie medzi odlišnými subordinačnými vzt’ahmi. Hansen a Ramm (2008) skúmajú diskurzívne sémantické aspekty subordinácie a koordinácie a hierarchickú//ne-hierarchickú organizáciu na úrovni vety a taktiež písaných a hovorených textov niekol'kých jazykov (anglický, nemecký, holandský, francúzsky a nórsky) s ciel'om prispiet' $\mathrm{k}$ lepšiemu pochopeniu ako sú informácie štruktúrované vo vetách a textoch $v$ jednotlivých jazykoch. V neposlednom rade, vel'kým prínosom $\mathrm{v}$ oblasti skúmania subordinácie vo vetách hovorených prejavov je aj práca Laury a Suzuky (2011), v ktorej podrobujú kritickej analýze východiskové syntaktické teórie o vzt'ahoch medzi vetami a ich relevantnost' k popisu kombinácií vetných štruktúr v konverzačnom jazyku, k štruktúre hovoreného prejavu a k interakčným funkciám jazyka.

Predmetom výskumu prezentovanom v práci sú syntaktické štruktúry vedl'ajších viet a subordinačné stratégie písomnej a ústnej formy anglického jazyka s ciel’om prispiet' k lepšiemu chápaniu kódovania informácií a ilokučných javov nielen na úrovni vety, ale aj širšieho kontextu. Výskum je založený na kvantitatívnej a kvalitatívnej analýze vlastného korpusu zostaveného $\mathrm{z}$ prirodzeného, kontextualizovaného jazyka používaného v štyroch odlišných typoch textov. Hlavný dôraz je kladený na funkčné aspekty, pričom dané formy sú uvádzané do súvislostí $\mathrm{s}$ ich funkčnými charakteristikami $v$ rôznych typoch textov a prehovorov. Skúmaný materiál pozostáva z odborných, umeleckých a publicistických textov a prepisov hovorených prejavov súčasnej britskej a americkej angličtiny. Texty zoskupené do jednotlivých typov sa odlišujú nielen frekvenčnou distribúciou gramatických štruktúr, ale aj mierou formálnosti štýlu. Medzi jednotlivými textami je evidentné kontinuum, počnúc od menej formálnych rozhovorov a beletrie, cez novinové články až po najformálnejšie odborné texty. Formálna a funkčná charakteristika analyzovaných štruktúr ponúka ucelený pohl'ad na jednotlivé typy vedl'ajších viet, ich diskurzívne funkcie a frekvenčnú distribúciu v hovorených prejavoch a písaných textoch.

\section{Ciel' práce}

Hlavným ciel’om práce je formálna a funkčná analýza využitia jednotlivých vetných typov v textoch rôznych štýlov a rôznej úrovne formálnosti. Práca skúma frekvenčnú distribúciu určitých a neurčitých nominálnych, relačných a adverbiálnych viet nielen na základe ich štrukturálnych a sémantických charakteristík, ale následne aj z hl'adiska funkčných aspektov. V neposlednom rade skúma aj dôvody determinujúce výber gramatických štruktúr, zobrazovanie vnútro vetných vzt’ahov používaných $\mathrm{v}$ interaktívnom jazyku v rámci skúmaného korpusu ako aj rozdiely $\mathrm{v}$ ich zastúpení v jednotlivých typoch textov. Analýza sa neobmedzuje iba na interpretáciu kvantitatívnych vzoriek, ale popri prezentácii frekvenčných dát a príkladov vzoriek, ponúka aj funkčné interpretácie vysvetl'ujúce, prečo daná vzorka existuje a ako sa používa. Predložená práca opisuje variácie jazyka a je zameraná skôr na overenie gramatickej teórie a vysvetlenie rozdielov vo využivaní subordinačných stratégií, než na vytvorenie určitých teórií. Po preštudovaní rôznych deskripcií štruktúry písomného a ústneho prejavu, ktoré dospeli k záveru, že vedl'ajšie vety sú rovnomerne zastúpené $\mathrm{v}$ každom $\mathrm{z}$ analyzovaných typov textov a ich funkcie sa do značnej miery zhodujú, a vychádzajúc $\mathrm{z}$ výskumného zamerania práce sme namiesto predloženia klasickej 
hypotézy sformulovali nasledujúcu výskumnú otázku: Aké formálne a funkčné vetné typy sú charakteristické pre jednotlivé analyzované texty a čo je prícinou uplatňovania rozdielnych subordinačných stratégií v hovorenom a pisanom prejave?

Ked’že zovšeobecňovanie výsledkov na základe skúmania iba jedného typu vedl'ajších viet by mohlo viest' $\mathrm{k}$ nepresným záverom týkajúcich sa odlišností jednotlivých textov, práca skúma frekvenčnú distribúciu troch centrálnych typov vedl'ajších viet $\mathrm{v}$ angličtine (nominálnych, relačných a adverbiálnych). Za účelom získania odpovedí na hore uvedené výskumné otázky, zistenia miery využívania subordinácie vodlišných typoch textov a skúmania subordinačných stratégií využívaných $\mathrm{v}$ daných textoch, našu analýzu sme zamerali na porovnanie distribúcie špecifických foriem subordinácie (výskyt určitých a neurčitých štruktúr), ich vetoslednej realizácii a v neposlednom rade aj na podobnosti a rozdiely v stratégiách používania vedl'ajších viet na pozadí diskurzívnych funkcií, ktoré plnia v skúmaných hovorených prejavoch a písaných textoch.

\section{Vymedzenie základnej terminológie \\ Hovorený a písaný prejav}

„The Cambridge Encyclopedia of the English Language“ (Crystal, 1997) definuje diskurz ako súvislý jazykový prejav, ktorý je dlhší ako veta. To znamená, že diskurz nepozostáva z izolovaných prehovorov vytrhnutých mimo kontextu, ale je to prirodzene sa vyskytujúci súvislý hovorený alebo písaný prejav, koherentný jazykový celok s definovatel'nou komunikatívnou funkciou, ako napr. konverzácia, opis, komentár, správa, písomná práca, poznámky a iné lingvistické aktivity.

Tradične sa jazyk delí na hovorený a písaný. Podla Crystala (ibid: 292) sa "rozdiel medzi týmito dvoma médiami zdá byt' na prvý pohl'ad zrejmý, ked’že vykazujú niekol'ko dôležitých rozdielov.“ V skutočnosti však tieto rozdiely nie sú tak jasné. Výsledky výskumov naznačujú, že v súčasnosti sa už nemôžeme pridržiavat' tradičného rozlišovania medzi hovoreným a písaným textom, ktoré sa nejaví byt' presvedčivým kritériom pre textovú variáciu. Niektoré hovorené prejavy používajú jazyk so špecifickými črtami písaného, vopred starostlivo pripraveného štruktúrovaného jazyka a naopak, niektoré druhy písaného jazyka môžu zdiel'at' charakteristické črty hovoreného jazyka (priame oslovenie adresáta, skrátené formy, atd'.) Biber (1999) a Chafe, Danielwicz (1987) tvrdia, že rozdiely medzi hovoreným a písaným médiom sú zapríčinené kontextom komunikácie, mentálnymi procesmi, ako aj časom, ktorý má používatel' jazyka k dispozícii pri plánovaní prehovoru. Tieto rozdiely sa prejavujú v používaní aj v štruktúre jazyka, ked’že hovoriaci aj pisatel' pôsobia $\mathrm{v}$ iných komunikatívnych situáciách, ale aj $\mathrm{v}$ nárokoch, ktoré jazykové prejavy kladú na poslucháča, resp. na čitatel'a (hovoriaci je vinterakcii s poslucháčom, kým pisatel' nie je), čo má vplyv aj na rozdiely medzi ústnym a písomným prejavom $\mathrm{v}$ syntaktickej komplexnosti. Na základe hore uvedených skutočností môžeme konštatovat', že rozdiely medzi hovorenou a písanou formou jazyka sa prejavujú skôr medzi jednotlivými typmi textov, než medzi samotnými médiami (Biber 1998 v Hudson-Ettle 1998).

\section{Typy textov}

Vety, resp. súvetia, či už písané, alebo hovorené, sa zriedkavo používajú izolovane, ale nachádzajú sa v sekvenciách, napr. v dialógoch, v súvislej reči, v článkoch, v liste, alebo v knihe atd'. Akúkol'vek takto zoskupenú koherentnú skupinu viet nazývame textom, čo je pomenovanie pre písaný a aj pre hovorený jazykový prejav. Pomenovanie „typ textu“ sme prevzali od Bibera (1988:70), ktorý ho používa na pomenovanie skupiny textov (hovorených a písaných), ktoré sú si podobné v zmysle ich lingvistickej formy. V svojej knihe Longman Grammar of Spoken and Written

XLinguae, Volume 11, Issue 2, April 2018, ISSN 1337-8384, eISSN 2453-711X 
English (LGSWE, 1999) používa Biber aj termín "register", ktorý sa vzt'ahuje na gramatickú charakteristiku daného typu textu. Výber textov pre náš výskum bol ovplyvnený práve Biberovou kategorizáciou textových variet (registrov) a pomenovanie „typ textu“ (text type) používame na pomenovanie súborov, resp. zoskupení textov jedného druhu, ktoré boli vybrané na základe externých kritérií vzt’ahujúcich sa na zámer autorov. Čo sa týka písaných textov použitých pre výskum, sú to printové média, napr. novinové články, kapitoly z beletrie, vedecko-populárne články a časti z akademických prác. Hovorený jazyk je zastúpený prepismi diskusií $\mathrm{s}$ rôznymi l'ud'mi v rozhlasových a televíznych reláciách. Zápisy rozhovorov sa líšia tematikou a aj úrovňou formálnosti so zretel’om na účastníkov diskusie.

\section{Veta}

Sprostredkúvané myšlienky a informácie sa vyjadrujú pomocou viet (clauses), ktoré sa môžu spájat' do väčších zmysluplných celkov, nazývaných súvetiami (sentences). Avšak vymedzenie pojmu ,veta“ je vel'akrát komplikované z niekol'kých dôvodov. Pod pojmom veta si zvyčajne predstavujeme napísanú myšlienku s vel'kým začiatočným písmenom a interpunkciou na jej konci. Pri počúvaní ústneho prejavu je niekedy t'ažké určit', ktoré štruktúry považovat' za vety. Kým v novinových článkoch a iných typoch písaných textov sú vety kompletné, mnohé z nich sú dlhé a štruktúrne komplexné, určit' vetu v konverzácii môže byt' problematické. Podl’a Bibera (1999) je „veta“ pojem, ktorý sa nedá aplikovat'v hovorenom jazyku; nie je l'ahké určit', kde sa veta začína a kde končí, ked’že neexistujú explicitné hranice (vel'ké písmená a bodky). Aby sme sa vyhli prípadným t’ažkostiam pri určovaní viet, použili sme pre potreby nášho výskumu hotové prepisy rozhovorov. Za vetu považujeme štruktúru vyjadrujúcu ucelenú myšlienku, pozostávajúcu zo skupiny slov obsahujúcej minimálne jeden podmet a určité sloveso, ohraničenú interpunkciou signalizujúcou jej koniec (bodka, otáznik, výkričník, úvodzovky).V prepisoch analyzovaných hovorených textov (konverzácia) sa popri nami definovaných vetách nachádza aj množstvo krátkych jedno až trojslovných štruktúr, ako napr. jednoduché odpovede (OK. Thanks. Well. Absolutely not. Yes. Oh, goodness, Larry. Sounds that way.) a nedokončených výpovedí. Niektoré z nich síce vyjadrujú ucelené myšlienky, avšak neobsahujú podmet a prísudok, preto sme ich nezahrnuli do nášho výskumu.

\section{Subordinácia - vedl'ajšie vety}

Podl'a A Comprehensive Grammar of the English Language (Quirk et al., 1985: 719) je subordinácia (podrad'ovanie) charakteristickou črtou anglickej 'complex sentrnce“ (podrad'ovacieho súvetia). „Subordinácia je spôsob spájania dvoch syntakticky nerovnocenných viet, jednej hlavnej, nezávislej (independent) a minimálne jednej vedl’ajšej (dependent) do súvetia, pričom sa hlavná veta stáva nadradenou vo vzt’ahu k vedl'ajšej vete, ktorá je významovo závislá na hlavnej.“ Zo sémantického hl'adiska je informácia obsiahnutá vo vedlajšej vete zvyčajne prezentovaná ako predpokladaná alebo sprievodná vo vzt’ahu k informácii obsiahnutej v nadradenej hlavnej vete. Vedl'ajšia veta môže vstúpit' do viacerých vzt’ahov v rámci súvetia, môže byt' podradenou jednej vete a byt' nadradenou inej vedl'ajšej vete:

(i) He told me [hlavná - nadradená vete (ii) ]

(ii) that Peter wouldn't go there [podradená vete (i)- nadradená vete (iii)]

(iii) unless they invite him.[podradená vete (ii)]

$\mathrm{V}$ takomto prípade sme $\mathrm{v}$ našom výskume každú $\mathrm{z}$ vedl'ajších viet analyzovali osobitne. Podrad'ovacie vety sa však môžu vyskytnút' aj na rovnakej úrovni, kde obe vety vystupujú ako rovnocenné.

(iv) What they do is what I don't like.

Podrad'ovacie súvetie (complex sentence) je vanglickej gramatike konštrukcia pozostávajúca $\mathrm{z}$ hlavnej a vedl'ajšej, resp. niekol'kých vedl'ajších viet, $\mathrm{v}$ ktorej vedl'ajšia veta/vety vystupuje/ú ako vetný člen, alebo modifikuje niektorý z vetných 
členov hlavnej vety. Subordinácia je zvyčajne signalizovaná podrad'ovacími spojkami, ktoré slúžia na označenie hraníc syntaktických štruktúr a zároveň naznačujú funkčné vzt'ahy medzi jednotlivými vetami v súvetí. Charakter vzt'ahu však nie je vždy explicitne označený, ked’že nie všetky podrad'ovacie vety sú uvádzané týmito spojkami. Ďalšími slovami signalizujúcimi podrad'ovanie sú $w h$-slová, slovo that, neurčité tvary a inverzia.

\section{Funkcie a formy vedl'ajš́ch viet}

Vedl'ajšie vety rozlišujeme na základe ich funkčných a sémantických princípov, napr. podl'a toho, či v súvetí vystupujú ako substantívum (nominal phrase), či determinujú podstatné meno, alebo majú adverbiálne funkcie. Cristofaro (2003) zdôrazňuje, že pre dosiahnutie ciel'a akéhokol'vek výskumu v oblasti vetnej skladby je funkčná definícia vel'mi dôležitá, to znamená, že nestačí iba jednoducho opísat' lingvistické štruktúry subordinácie, ale treba poskytnút' aj funkčno-kognitívne vysvetlenie používania týchto štruktúr. V predloženej práci sú vedl'ajšie vety z funkčného hl'adiska rozdelené do troch základných kategórií (podl'a CGEL,1985) na nominálne (nominal clauses) ,vzt'ažné (relativel clauses) a adverbiálne (adverbial clauses). V závislosti na tvare slovesa vo vete sa anglické vedl'ajšie vety z formálneho hl'adiska delia na určité (finite) a neurčité (non-finite). Určitá vedl'ajšia veta je obvykle označená spojkou, $w h$-slovom, alebo slovom that. Okrem týchto indikátorov podrad'ovania to môže byt' aj inverzia. Neurčité vedl'ajšie vety zvyčajne nie sú uvádzané týmito spájajúcimi slovami, ale obsahujú neurčité štruktúry, ku ktorým patrí infinitív, particípiá a gerundium.

\section{Charakteristika analyzovaného korpusu}

L’udia používajú odlišné variety jazyka v súlade s rôznymi situáciami a kontextom (napr. rozprávanie s priatel’om, čítanie novín, kníh, písanie listov, odborná prednáška, atd'.), v ktorom ho produkujú. Skúmanie charakteristík a rozdielov týchto variet zastúpených $\mathrm{v}$ rôznych typoch textov nám môže skôr pomôct' odhalit' typické modely ako vynášat' úsudky o ich gramatickej správnosti. Hl'adanie typických modelov si vyžaduje analýzu obrovského množstva jazyka zozbieraného od mnohých hovoriacich alebo z množstva písaných textov. Takéto analýzy sú zamerané na zhodnotenie rozsahu v ktorom sa určitý model vyskytuje a na kontextuálne faktory, ktoré ovplyvňujú variabilitu textu.

Pre účely nášho výskumu sme zostavili korpus $\mathrm{z}$ autentických anglický hovorených/písaných rôznych štýlov, ktoré predstavujú materiálové východisko analýzy. Celý korpus pozostáva zo štyroch subkorpusov: hovorené texty (neformálne konverzácie - interview), odborné texty, publicistické texty (novinové články) a umelecká beletria. Každý z týchto subkorpusov zahŕňa asi 30000 slov, spolu sa teda boli analyzované texty s rozsahom 120000 slov. Všetky typy textov sú jazykovými prejavmi súčasnej britskej a americkej angličtiny rôznej úrovne formálnosti. Texty vytvárajúce jednotlivé subkorpusy pre účely analýzy boli náhodne vybraté nehl'adiac na typ média, tému, úroveň jazyka, vek, sociálne postavenie, resp. pohlavie používatel'ov jazyka. Hovorené texty boli zozbierané z televíznych a rozhlasových „talk-show“, živých konverzácií, v ktorých zvyčajne vystupoval hostitel' a host' (známa osobnost', ako napr. politik, herec, spevák, športovec, spisovatel'), ktorí diskutovali na témy bežného života. Korpus odborných textov pozostáva z prednášok, vedeckých článkov a častí akademickej literatúry z rôznych vedeckých oblastí (ekonomika, medicína, psychológia, pedagogika, environmentalistika). Analyzované publicistické texty pochádzajú z dennej tlače a týždenníkov, zahŕňajú širokú škálu námetov, ako napr. domáce a zahraničné správy, umenie (výtvarné umenie, divadlo,

XLinguae, Volume 11, Issue 2, April 2018, ISSN 1337-8384, eISSN 2453-711X 
film, móda), spoločnost', l’udia, životné prostredie, životný štýl, kriminalita a iné. Posledný typ textov, ktorý sme podrobili analýz sú umelecké texty pozostávajúce z určitého počtu kapitol štyroch rôznych žánrov (ženský román, detektívka, sciencefiction a dobrodružný román).

\section{Analýza textov z hl’adiska výskytu odlišných formálnych a funkčných typov vedl'ajších viet}

Vychádzajúc z ciel'ov výskumu, ktorý bol zameraný na zistenie a porovnanie výskytu odlišných formálnych a funkčných typov vedl'ajších viet, súčast'ou analýzy

bolo aj porovnanie výskytu určitých (finite) a neurčitých (non-finite) štruktúr vedl'ajších viet. Z celkového počtu 6557 viet sa v korpuse nachádza 5820 vedl'ajších viet. Pomer určitých (4374) a neurčitých (1446) štruktúr je približne 3:1. Graf 1 zobrazuje distribúciu spomínaných štruktúr vedl'ajších viet v jednotlivých typoch textov.

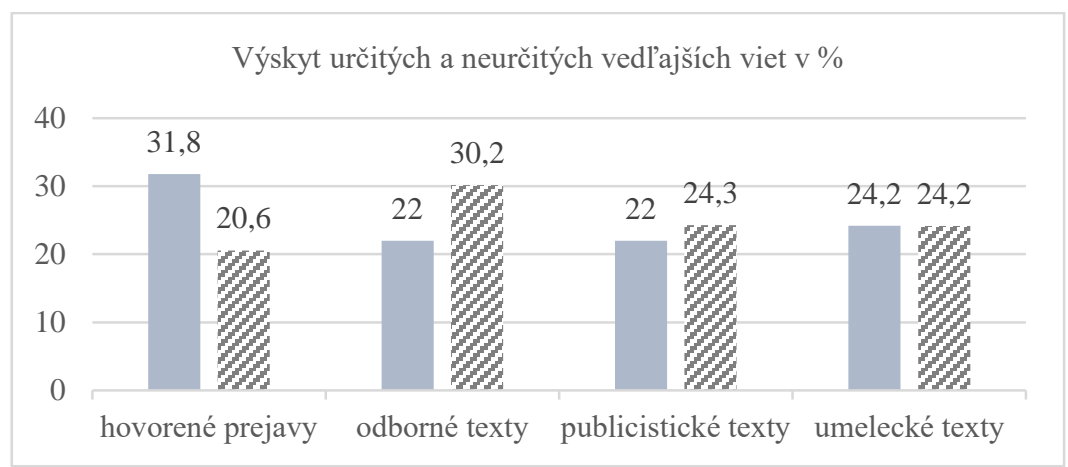

\section{Graf 1 Distribúcia určitých a neurčitých vedl'ajších viet $\mathrm{v}$ textoch}

$\mathrm{Na}$ základe percentuálneho zastúpenia určitých a neurčitých viet $\mathrm{v}$ jednotlivých typoch textov sme došli k záveru, že frekvencia výskytu týchto štruktúr závisí od miery formálnosti textu. Určité vedl'ajšie vety sú typické pre menej formálne texty (hovorené prejavy a odborné texty), kým neurčité vedl'ajšie vety sú príznačné pre formálny typ textov (odborná literatúra a publicistické texty).

Za účelom získania odpovedí na naše výskumné otázky či odlišné typy textov využívajú odlišné formálne a funkčné typy podrad'ovacích viet, ktoré typy vedl'ajších viet sú charakteristické pre konkrétny text a či možno vymedzit' vzorce, ktoré sú typické pre distribúciu vedl'ajších viet $\mathrm{v}$ hovorenom a písanom prejave, analýza textov bola zameraná na frekvenčnú distribúciu nominálnych, vzt'ažných a adverbiálnych vedl'ajších viet v skúmaných textoch a na funkcie, ktoré v nich plnia. Dáta v Tabul'ke 1 znázorňujú frekvenčnú distribúciu jednotlivých funkčných typov vedlajších viet $\mathrm{v}$ analyzovaných textoch ústneho a písomného prejavu.

Tabul'ka 1 Distribúcia funkčných typov vedl’ajších viet v rámci celého korpusu

\begin{tabular}{|l|c|c|c|c|c|c|c|c|}
\hline Celý korpus & \multicolumn{2}{|c|}{ nominálne } & \multicolumn{2}{c|}{ vzt’ažné } & \multicolumn{2}{c|}{ adverbiálne } & \multicolumn{2}{c|}{ celkom } \\
\hline typ textu & počet & $\%$ & počet & $\%$ & počet & $\%$ & počet & $\%$ \\
\hline $\begin{array}{l}\text { hovorené } \\
\text { prejavy (HP) }\end{array}$ & 766 & 33,7 & 463 & 25,2 & 458 & 26,7 & $\mathbf{1 6 8 7}$ & $\mathbf{2 9 , 0}$ \\
\hline $\begin{array}{l}\text { odborné texty } \\
\text { (OT) }\end{array}$ & 558 & 24,6 & 438 & 23,9 & 403 & 23,5 & $\mathbf{1 3 9 9}$ & $\mathbf{2 4 , 1}$ \\
\hline
\end{tabular}




\begin{tabular}{|l|c|c|c|c|c|c|c|c|}
\hline $\begin{array}{l}\text { publicistické } \\
\text { texty (PT) }\end{array}$ & 471 & 20,8 & 451 & 24,6 & 390 & 22,7 & $\mathbf{1 3 1 2}$ & $\mathbf{2 2 , 5}$ \\
\hline $\begin{array}{l}\text { umelecké texty } \\
\text { (UT) }\end{array}$ & 475 & 20,9 & 482 & 26,3 & 465 & 27,1 & $\mathbf{1 4 2 2}$ & $\mathbf{2 4 , 4}$ \\
\hline celkom & $\mathbf{2 2 7 0}$ & & $\mathbf{1 8 3 4}$ & & $\mathbf{1 7 1 6}$ & & $\mathbf{5 8 2 0}$ & $\mathbf{1 0 0}$ \\
\hline celkom \% & $\mathbf{3 9 , 0}$ & & $\mathbf{3 1 , 5}$ & & $\mathbf{2 9 , 5}$ & & $\mathbf{1 0 0}$ & \\
\hline
\end{tabular}

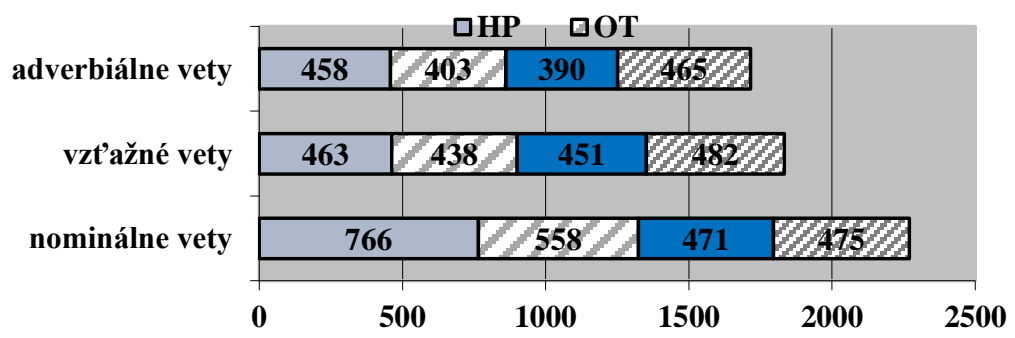

Graf 2 Distribúcia funkčných typov vedl'ajších viet v rámci textov

Nominálne vety - ich výskyt, formy a funkcie v skúmaných textoch

$\mathrm{Na}$ základe skúmania textov $\mathrm{z}$ hl’adiska frekvenčnej distribúcie sme zistili, že vedl'ajšie vety nominálne sú najrozšírenejším typom vedl'ajších viet v skúmanom korpuse štyroch typov textov. Nominálnymi vetami nazývame $\mathrm{v}$ anglickej gramatike vedl'ajšie vety, ktoré majú vo vete tie isté funkcie ako substantíva, t.j. môžu vyjadrovat' podmet, predmet, doplnok, alebo môžu byt' vo funkcii prístavku. Nominálne vedlajšie vety sme rozdelili do nasledujúcich formových kategórií: určité vety uvádzané slovom that a wh- (finite that-clauses and wh-clauses) a neurčité infinitivne a ing- vety (non-finite to-infinitive and ing-clauses). Z celkového počtu 2270 nominálnych štruktúr je 1663 (73,3\%) určitých a 26,7\% neurčitých. Tabul'ka 2 zobrazuje distribúciu určitých a neurčitých nominálnych viet v jednotlivých skúmaných textoch.

Tabul'ka 2 Distribúcia formálnych typov nominálnych vedl’ajších viet $\mathrm{v}$ rámci textov

\begin{tabular}{|l|c|c|c|c|c|c|}
\hline $\begin{array}{l}\text { Nominálne } \\
\text { vety }\end{array}$ & \multicolumn{2}{|c|}{ určité } & \multicolumn{2}{c|}{ neurčité } & \multicolumn{2}{c|}{ celkom } \\
\hline typ textu & počet & $\%$ & počet & $\%$ & počet & $\%$ \\
\hline $\begin{array}{l}\text { hovorené } \\
\text { prejavy }\end{array}$ & 587 & 35,3 & 179 & 25,2 & $\mathbf{7 6 6}$ & $\mathbf{3 3 , 7}$ \\
\hline odborné texty & 363 & 21,8 & 195 & 23,9 & $\mathbf{5 5 8}$ & $\mathbf{2 4 , 6}$ \\
\hline $\begin{array}{l}\text { publicistické } \\
\text { texty }\end{array}$ & 362 & 21,8 & 109 & 24,6 & $\mathbf{4 7 1}$ & $\mathbf{2 0 , 8}$ \\
\hline umelecké texty & 351 & 21,1 & 124 & 26,3 & $\mathbf{4 7 5}$ & $\mathbf{2 0 , 9}$ \\
\hline Celkom & $\mathbf{1 6 6 3}$ & & $\mathbf{6 0 7}$ & & $\mathbf{2 2 7 0}$ & $\mathbf{1 0 0}$ \\
\hline Celkom \% & $\mathbf{7 3 , 3}$ & & $\mathbf{2 6 , 7}$ & & & \\
\hline
\end{tabular}

Hovorené prejavy vykazujú najvyššie percento $(33,7 \%)$ všetkých nominálnych viet, čo sa dá vysvetlit' tým, že v anglickom ústnom prejave je vel'mi vysoká frekvencia slovies think, say a know, slovies zmyslového vnímania a iných performatívnych

XLinguae, Volume 11, Issue 2, April 2018, ISSN 1337-8384, eISSN 2453-711X 
slovies, ktoré sú v angličtine vždy sprevádzané nominálnymi vedl’ajšími vetami. Nominálne vety sú $\mathrm{v}$ tomto médiu v prevažnej miere zastúpené určitými vedl'ajšími vetami, kým najviac neurčitých tvarov vedl'ajších viet môžeme nájst' v odborných textoch (32,1\%). Výsledky analýzy potvrdzujú teóriu Beamanovej (1984), Greenbauma (1996) a Bibera (1999), ktorí tvrdia, že frekvencia výskytu určitých nominálnych viet je v ústnom prejave podstatne vyššia ako v písomnom prejave.

Nominálne vety v anglickom jazyku majú určité syntaktické a diskurzívne funkcie. Väčšina nominálnych viet $(88 \%)$ sa nachádza v post-predikatívnej pozícii (za slovesom) vo funkcii objektu, napr. I just think that all the ingredients are there, kým pozícia nominálnej vedlajšej vety pred slovesom (subjektová) je v angličtine vel'mi zriedkavá. Vysoká frekvencia výskytu nominálnych viet vo funkcii objektu (56\%) je dôsledkom vysokého počtu a širokej palety performatívnych slovies uvádzajúcich nepriamu reč, vyjadrujúcich postoje, myšlienky a pocity, ktoré si v anglickom jazyku vyžadujú doplnenie nominálnymi vetami. Výsledky výskumu ukazujú, že post predikatívna pozícia je najbežnejšia $\mathrm{v}$ rozhovoroch a v umeleckých textoch, kde sa za slovesom nachádza až $94 \%$, resp. 90\% nominálnych viet. Subjektové nominálne vety prezentujúce faktické informácie o referentovi (That he should sit there so quietly in the field didn't surprise me.) zvyčajne preberajú štrukturálnu alternatívu (extraposed subject) $\mathrm{k}$ iniciálnej pozícii vo vete (It didn't surprise me that he should sit there so quietly in the field.). Tzv. „odsunuté“ subjektové vety sa najčastejšie nachádzajú v publicistických textoch a odborných textoch, kde oznamujú postoj pisatel'a, ktorý nie je zjavne prisúdený žiadnej osobe.

Ďalšími častými funkčnými typmi nominálnych viet sú v skúmanom korpuse doplnkové (complement) vety, ktoré zvyčajne opisujú podstatu nejakého problému alebo prezentujú príčiny, výsledky, zhrnutia a fakty (The truth was that his accountant was trying like hell to stop him.) a prístavkové (appositive) vety, ktoré identifikujú, resp. vysvetl'ujú substantívum, ktoré sa nachádza bezprostredne pred nimi (It differs from the claim that intelligence is made possible only by specific biochemical properties of neural tissue.). Prístavkové vety sú charakteristické predovšetkým pre odborné texty, kde je množstvo informácií sprostredkovaných substantívnymi výrazmi (nominal phrases) a prístavkové vety sú potrebné pre ich následné objasnenie. Tento spôsob komplementácie substantíva (apozícia) je však najmenej používaný v ústnom prejave. Nerovnomernú distribúciu prístavkových viet môžeme pripísat' faktu, že odborné texty sú zamerané skôr na sprostredkúvanie a upresňovanie informácie, menej na osobné stanoviská a reakcie, ako tomu je v skúmaných prepisoch ústnej interakcie (Rafajlovičová, 2015:124).

Najpočetnejšie zastúpenie $\mathrm{v}$ skúmaných textoch majú určité štrukturálne typy nominálnych viet, ktoré sú uvádzané spájacími prostriedkami that a wh- slovami. $\mathrm{Z}$ nich tvoria vety pripojené $\mathrm{k}$ hlavnej vete spojkou that (that-clauses a zero thatclauses) 49,8\% všetkých (určitých aj neurčitých) nominálnych vedlajších viet. Tento typ sa najčastejšie vyskytuje v odborných publicistických textoch, kde sa používa na sprostredkúvanie výpovedí, vyjadrovanie myšlienok, emócií, mentálnych stavov a postojov pisatel'ov, čo je charakteristické pre tieto štýly písomného prejavu. Naopak, vety $\mathrm{s}$ wh- spojkami sa najčastejšie používajú $\mathrm{v}$ neformálnych prejavoch, v našom prípade $\mathrm{v}$ ústnych prejavoch a umeleckých textoch. V týchto médiách sa zvyčajne používajú po slovesách know a ask, v nepriamych otázkach, alebo po komunikačných, kognitívnych a percepčných slovesách ako tell, decide, realize, see, wonder v takých situáciách, v ktorých hovoriaci/rozprávač prezentuje určité fakty alebo problémy. Približne $50 \%$ všetkých viet sa nachádza v tejto pozícii. Vety začínajúce $\mathrm{s} w h$ plnia tie isté funkcie ako vety uvádzané slovom that, môžeme ich však častejšie nájst' aj vo 
funkcii subjektu, teda pred slovesom (What bothered me that morning was disquiet, a physical sensation I couldn't identify.).

Naopak, neurčité štrukturálne typy vedl'ajších viet, gerundiálne a infinitívne (-ing, toinfinitive) dominujú $\mathrm{v}$ písomnom prejave. Najčastejšie používaným tvarom vo všetkých štyroch typoch skúmaných textov je infinitív (61,5\%), ktorého najvyššiu frekvenciu výskytu sme zaznamenali v hovorených textoch a v beletrii. Infinitívne, čiže neurčitkové vety spíňajú v ústnych prejavoch a umeleckých textoch zvyčajne funkciu objektu a sú najčastejšie riadené slovesami want, would like, try, hope, a decide. Vedl'ajšie vety po týchto slovesách vyjadrujú osobné túžby (I just don't want to be there.) účastníkov rozhovoru $\mathrm{v}$ ústnom aj písomnom prejave. Okrem spomínaných slovies sa neurčitkové vety často používajú so slovesami vyjadrujúcimi úsilie (try), oznamujúcimi stav progresie danej aktivity (start, begin) alebo opisujúcimi postoj k predvídanému činu (love, like, seem) vyjadrenému neurčitkom. Ing-ové tvary neurčitých nominálnych viet sú charakteristické pre formálne, teda odborné texty, zastupujú širokú škálu funkcií a najčastejšie sa nachádzajú v post predikatívnej pozícii za slovesami odlišných sémantických domén a za adjektívami v konštrukciách s predložkami. Tieto neurčité vedl'ajšie vety opisujú procesy, poskytujú vysvetlenia teórií, resp. vyjadrujú určité postoje alebo hodnotenia, čo je typické pre odborný štýl, napr. People's standard of living cannot increase by mining more gold, alebo Bronchitis is prevented by keeping good health habits and by giving instant treatment to milder respiratory infections.

Celkové výsledky poukazujú na nasledujúci fakt, čím je vyššia frekvencia nominálnych viet $\mathrm{v}$ danom type textu, tým je text menej formálny, na základe čoho môžeme predpokladat', že nominálne vety sú črtou neformálnosti.

\section{Vzt’ažné vety - ich výskyt, formy a funkcie v skúmaných textoch}

Vzt'ažné vety $\mathrm{v}$ anglickej gramatike nájdeme pod pojmom relative clauses, čím rozumieme typ vedl'ajších viet, ktoré majú v rámci súvetia funkciu determinujúceho prvku, teda špecifikujú, resp. bližšie určujú ktorékol’vek substantívum/substantíva hlavnej vety alebo sa vzt'ahujú na obsah hlavnej vety. Tieto vedl'ajšie vety sa v anglickom jazyku nachádzajú výlučne za substantívom, ktoré determinujú, alebo za hlavnou vetou, ktorej obsah hodnotia a sú spojené s hlavnou vetou spájacími operátormi, relatívami (relativizers): that, who, whom, which, whose, when, where a why. $\mathrm{V}$ niektorých prípadoch sa však operátor vynecháva (zero-relativizer), čo je bežným javom predovšetkým v neformálnom hovorovom štýle (This should not be something [that] the United States does alone.).

Celkový počet vzt'ažných viet je v skúmanom korpuse 1834, čo predstavuje 31,5\% zo všetkých subordinačných štruktúr. Tieto čísla nám naznačujú, že vzt'ažné vety sú druhým najrozšírenejším funkčným typom vedl'ajších viet v anglickom jazyku (pozri tabul'ku 1). Najpočetnejšie zastúpenie tohto typu vedl'ajších viet môžeme nájst' v umeleckých textoch, čo plne korešponduje so zisteniami z predchádzajúcich analýz $\mathrm{v}$ rôznych korpusoch, kde sa konštatuje, že „Vzt'ažné vety sú pomerne časté vo všetkých troch pisaných registroch. Proporcionálne sú najčastejšie v beletrii." [" Relative clauses are relatively frequent in all three written registers. Proportionally, they are most common in fiction" (Biber et al, 1999:8.6.1).] Naopak, Prideaux (1993), vychádzajúc zo svojho výskumu tvrdí, že vzt’ažné vety sú ovel’a častejšie v hovorených textoch, ako písaných. (Rafajlovičová, 2013)

Kým rozdiely vo frekvencii výskytu vzt’ažných viet medzi skúmanými textami v našom korpuse sú nepatrné (pozri tabul'ku 1), na základe čoho môžeme konštatovat', že determinácia relatívnymi vetami nie je indikátorom formálnosti textov.

XLinguae, Volume 11, Issue 2, April 2018, ISSN 1337-8384, eISSN 2453-711X 
Signifikantný rozdiel sme však zaznamenali v distribúcii formálnych typov vetných štruktúr. Získané údaje zobrazené v Tabul'ke 3 poukazujú, že pomer určitých a neurčitých vzt'ažných viet vyskytujúcich sa v korpuse je približne 3:1 v prospech určitých, čo je približne rovnaký pomer ako u nominálnych viet.

Tabul'ka 3 Distribúcia formálnych typov nominálnych vedl’ajších viet $\mathrm{v}$ rámci textov

\begin{tabular}{|l|c|c|c|c|c|c|}
\hline Vzt’ažné vety & \multicolumn{2}{|c|}{ určité } & \multicolumn{2}{c|}{ neurčité } & \multicolumn{2}{c|}{ celkom } \\
\hline Typ textu & počet & $\%$ & počet & $\%$ & počet & $\%$ \\
\hline $\begin{array}{l}\text { hovorené } \\
\text { prejavy }\end{array}$ & 418 & 29,7 & 45 & 10,6 & & \\
\hline odborné texty & 308 & 21,9 & 130 & 30,6 & & \\
\hline $\begin{array}{l}\text { publicistické } \\
\text { texty }\end{array}$ & 323 & 22,9 & 128 & 30,1 & & \\
\hline umelecké texty & 360 & 25,5 & 122 & 28,7 & & \\
\hline Celkom & $\mathbf{1 4 0 9}$ & & $\mathbf{4 2 5}$ & & $\mathbf{1 8 3 4}$ & $\mathbf{1 0 0}$ \\
\hline Celkom \% & $\mathbf{7 6 , 8}$ & & $\mathbf{2 3 , 2}$ & & & \\
\hline
\end{tabular}

Z percentuálneho zastúpenia určitých a neurčitých vzt'ažných viet vjednotlivých typoch textov je však evidentné, že väššina určitých tvarov vzt'ažných viet sa nachádza $\mathrm{v}$ hovorených prejavoch, teda $\mathrm{v}$ ústnej komunikácii a umeleckých textoch a najmenej $\mathrm{v}$ textoch odborného a publicistického štýlu (It had failed because of an error that everybody could understand.). Dva posledné spomenuté formálne typy textov naopak obsahujú najvyšší počet neurčitých tvarov, ktorých používanie je uprednostňované $\mathrm{z}$ „ekonomických“ dôvodov tam, kde je potreba vyjadrit' tie isté myšlienky a významy v skrátenej podobe (One of the more thorny problems discussed at the conference was the new estates that had been built in the past 20 years.). Neurčité, čiže skrátené tvary vzt’ažných viet, sa v anglickom jazyku nachádzajú $\mathrm{v}$ tvare particípií (-ing, ed- participle) a infinitívu (to- inf.). Najčastejšie používané neurčité tvary sú minulé $(45 \%)$ a prítomné $(42,6 \%)$ particípium, ktorých frekvencia je vyššia $\mathrm{v}$ písomnom ako $\mathrm{v}$ ústnom prejave. $\mathrm{V}$ porovnaní $\mathrm{s}$ nimi sú neurčitkové vety (to- inf.) vel'mi zriedkavé vo všetkých typoch textov.

Vychádzajúc $\mathrm{z}$ hore uvedených zistení môžeme konštatovat', že distribúcia určitých a neurčitých vzt’ažných viet je určovaná médiom a štylistickou príbuznost'ou a že použivanie určitých tvarov je charakteristické pre neformálny jazyk, kým neurčité tvary sú doménou formálneho jazyka (Rafajlovičová, 2015).

Výber relatíva, spájacieho vedlajšie vety s hlavnými, závisí od niekol'kých činitel’ov so zretel’om na poskytovanú informáciu (reštriktívna/nereštriktívna), na determinované substantívum (životné/neživotné) a na funkciu, resp. pozíciu substantíva (subjekt, objekt), na ktoré sa vedl'ajšia veta vzt'ahuje. Vd’aka vysokému gramatickému potenciálu je najčastejšie použivaným relatívom v určitých vetách that, ktoré sa $\mathrm{v}$ angličtine používa výhradne iba $\mathrm{v}$ reštriktívnych vetách. That je najflexibilnejšie zo všetkých relatív, ked’že sa môže používat' nielen so životnými, ale aj s neživotnými substantívami a neurčitými zámenami a navyše môže determinovat' substantíva $\mathrm{v}$ rôznych pozíciách. Najvyššiu frekvenciu používania that sme zaznamenali v odborných textoch. Wh- slová nie sú také flexibilné ako that a to aj napriek tomu, že sa používajú v reštriktívnych aj nereštriktívnych vedl'ajších vetách. Z nich najčastejšie používané je which, ktoré sa môže vzt'ahovat' iba na neživotné podstatné mená. Najčastejšie sa vyskytuje v menej formálnom umeleckom písomnom 
prejave, v beletrii. Graf 3 zobrazuje distribúciu operátorov that a which v určitých a neurčitých štruktúrach vzt’ažných viet v korpuse.

\section{Percentuálny výskyt which a that $\mathrm{v}$ textoch}

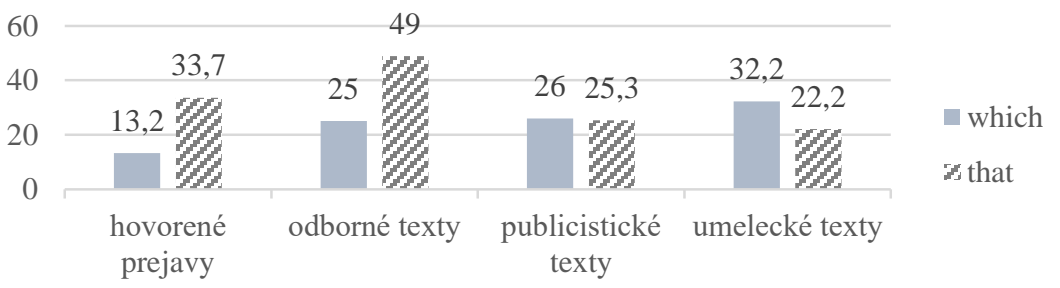

\section{Graf 3 Distribúcia relatív which a that v skúmanom korpuse}

Anglické vedl'ajšie vety vzt'ažné zo sémantického hl'adiska rozdel'ujeme na reštriktívne (restrictive), ktoré špecifikujú podstatný identifikačný znak substantíva a nereštriktívne (non-restrictive), podávajúce identifikačne nerelevantnú informáciu o substantíve. Analýza textov z hl'adiska zastúpenia reštriktívnych a nereštriktívnych určitých a neurčitých vzt'ažných viet nám poskytla tiež hodnotné informácie o syntaktickej a sémantickej štruktúre skúmaných textov.

Tabul'ka 4 Distribúcia reštriktívnych a nereštriktívnych určitých a neurčitých vzt’ažných viet $\mathrm{v}$ anglickom jazyku

\begin{tabular}{|c|c|c|c|c|c|c|c|c|c|c|}
\hline $\begin{array}{c}\text { celý } \\
\text { korpus }\end{array}$ & \multicolumn{3}{|c|}{ reštriktívne } & \multicolumn{5}{c|}{ nereštriktívne } & \multicolumn{2}{c|}{ celkom } \\
\hline $\begin{array}{c}\text { typ } \\
\text { textu }\end{array}$ & $\begin{array}{c}\text { Urči } \\
\text { té }\end{array}$ & $\begin{array}{c}\text { Neur } \\
\text { č. }\end{array}$ & $\begin{array}{c}\text { Počet } \\
\%\end{array}$ & $\begin{array}{c}\text { Urči } \\
\text { té }\end{array}$ & $\begin{array}{c}\text { Neur } \\
\text { č. }\end{array}$ & $\begin{array}{c}\text { Počet } \\
\%\end{array}$ & \multicolumn{2}{c|}{$\begin{array}{c}\text { Počet } \\
\%\end{array}$} \\
\hline $\begin{array}{l}\text { hovorené } \\
\text { prejavy }\end{array}$ & 364 & 39 & $\begin{array}{c}40 \\
3\end{array}$ & 21.9 & 54 & 6 & 60 & 3.3 & $\mathbf{4 6 3}$ & $\mathbf{2 5 . 2}$ \\
\hline $\begin{array}{l}\text { odbrné } \\
\text { texty }\end{array}$ & 261 & 110 & $\begin{array}{c}37 \\
1\end{array}$ & 20.3 & 47 & 20 & 67 & 3.6 & $\mathbf{4 3 8}$ & $\mathbf{2 3 . 9}$ \\
\hline $\begin{array}{l}\text { publicisti } \\
\text { cké texty }\end{array}$ & 233 & 102 & $\begin{array}{c}33 \\
5\end{array}$ & 18.3 & 90 & 26 & 116 & 6.3 & $\mathbf{4 5 1}$ & $\mathbf{2 4 . 6}$ \\
\hline $\begin{array}{l}\text { umeleck } \\
\text { é texty }\end{array}$ & 309 & 78 & $\begin{array}{c}38 \\
7\end{array}$ & 21.1 & 51 & 44 & 95 & 5.2 & $\mathbf{4 8 2}$ & $\mathbf{2 6 . 3}$ \\
\hline $\begin{array}{c}\text { celkom } \\
\text { celkom } \\
\mathbf{\%}\end{array}$ & $\mathbf{6 3 . 5}$ & $\mathbf{1 7 . 9}$ & $\mathbf{9 6}$ & $\mathbf{8 1 . 6}$ & $\mathbf{1 3 . 2}$ & $\mathbf{5 . 2}$ & & $\mathbf{1 8 . 4}$ & & $\mathbf{1 0 0}$ \\
\hline
\end{tabular}

Výsledky prezentované $\mathrm{v}$ tabul'ke 4 poukazujú na fakt, že reštriktívne vedl'ajšie vety s výskytom $81,6 \%$ podstatne prevažujú nad nereštriktívnymi. Ďalšia analýza ukázala, že celkový výskyt týchto dvoch funkčných typov vzt’ažných viet je determinovaný médiom a zároveň úrovňou formálnosti. Napriek tomu, že rozdiely v distribúcii reštriktívnych vzt’ažných viet nie sú významné, môžeme pozorovat' miernu postupnost' $v$ náraste ich výskytu $(18,3 \%$ až $21,9 \%)$ od najnižších hodnôt vo formálnych textoch až po najvyššie hodnoty $\mathrm{v}$ menej formálnych textoch. V hovorených prejavoch a umeleckých textoch, ktoré sú považované za menej formálne, sa nachádza viac reštriktívnych viet a to vd’aka množstvu všeobecných podstatných mien (thing, people, man, child, friend, atd'.) a neurčitých zámen (somebody, someone, something, anything, everything), ktoré si v anglickom jazyku

XLinguae, Volume 11, Issue 2, April 2018, ISSN 1337-8384, eISSN 2453-711X 
vyžadujú identifikáciu, resp. špecifikáciu. Naopak, najvyššia frekvencia výskytu $(6,3 \%$ a $5,2 \%)$ nereštriktívnych viet sa vo formálnych odborných a publicistických textoch dá vysvetlit' výskytom vlastných mien, ktoré si nevyžadujú identifikáciu, preto sú doplnené iba informáciami, ktoré nie sú podstatné pre bližšiu špecifikáciu podstatného mena.

\section{Adverbiálne vety - ich výskyt, formy a funkcie v skúmaných textoch}

Adverbiálne vedl'ajšie vety môžu byt' vyjadrené širokou škálou štruktúr, ktoré sa odlišujú v zmysle foriem (určité/neurčité), sémantických vzt'ahov a tvrdení (Diessel, 2011) . Sú to vedl'ajšie vety, ktoré majú v súvetí funkciu adverbií, to znamená, že upresňujú, bližšie určujú alebo inak modifikujú dej, udalost', resp. stav, ktorý je vyjadrený predikátom/slovesom hlavnej vety. Podávajú informácie o tom, kde, kedy, prečo, ako a za akým účelom sa dej hlavnej vety odohral, vyjadrujú podmienky platnosti deja, jeho dôsledok, atd'. Termín ,adverbiálna veta“ je sa v tejto práci používa ako všeobecné označenie, ale $\mathrm{v}$ skutočnosti funkcia tohto typu vedl'ajšej vety nie je vždy modifikácia slovesa v hlavnej vete, ale tieto vety sa často vzt'ahujú aj na iný aspekt hlavnej vety, ako napríklad na jej ilukočnú silu a môžu vytvárat' dodatočné vzt’ahy za hranicou hlavnej vety v súvetí .

Analýza korpusu nám poskytla informácie o frekvenčnej distribúcii tohto typu vedl'ajších viet, ich sémantických kategóriách, gramatických formách a pozícii vo vete. Výskum bol zameraný aj na základné rozdiely medzi spojkami používanými na pripojenie vedl'ajších viet k hlavnej vete. Počet adverbiálnych viet v korpuse je 1716, čo predstavuje $29,5 \%$ všetkých vedlajších viet nájdených v korpuse. Ich distribúcia $\mathrm{v}$ jednotlivých typoch textov naznačuje, že ich používanie je charakteristické pre menej formálny anglický jazyk. Najviac sa nachádzajú v beletrii (27.1\%) a rozhovoroch $(26.7 \%)$. Môžeme to vysvetlit' tým, že v beletrii a ústnom prejave je obvyklé, že opisy udalostí sú d’alej rozvíjané dodatočnými informáciami a vysvetleniami, ktoré poskytujú temporálne, kauzatívne, koncesívne, kondicionálne a iné interpretácie. Ak porovnáme frekvenčnú distribúciu troch typov nami skúmaných vedl'ajších viet $\mathrm{v}$ korpuse, adverbiálne vety majú najnižšie zastúpenie (pozri tabul'ku 1), hoci rozdiel medzi nimi a relatívnymi vetami je zanedbatel'ný.

Tabul'ka 4 zobrazuje zastúpenie formálnych kategórí adverbiálnych viet v celom korpuse, ako aj v jednotlivých skúmaných textoch. Ak porovnáme výsledky zobrazené v tabul'ke s výsledkami nominálnych (Tabul'ka 2) a vzt'ažných viet (Tabul'ka 3), zistíme, že podobne ako pri spomínaných vedl'ajších vetách, drvivá väčšina adverbiálnych viet je tiež určitá $(75,8 \%)$.

Tabul'ka 8 Distribúcia určitých a neurčitých adverbiálnych viet

\begin{tabular}{|l|c|c|c|c|c|c|}
\hline $\begin{array}{l}\text { Adverbiálne } \\
\text { vety }\end{array}$ & \multicolumn{2}{|c|}{ určité } & \multicolumn{2}{c|}{ neurčité } & \multicolumn{2}{c|}{ celkom } \\
\hline typ textu & počet & $\%$ & počet & $\%$ & počet & $\%$ \\
\hline $\begin{array}{l}\text { hovorené } \\
\text { prejavy }\end{array}$ & 384 & 22,4 & 74 & 4,3 & $\mathbf{4 5 8}$ & $\mathbf{2 6 , 7}$ \\
\hline odborné texty & 291 & 17,0 & 112 & 6,5 & $\mathbf{4 0 3}$ & $\mathbf{2 3 , 5}$ \\
\hline $\begin{array}{l}\text { publicistické } \\
\text { texty }\end{array}$ & 276 & 16,0 & 114 & 6,7 & $\mathbf{3 9 0}$ & $\mathbf{2 2 , 7}$ \\
\hline $\begin{array}{l}\text { umelecké texty } \\
\text { Celkom }\end{array}$ & $\mathbf{1 3 0 2}$ & 20,4 & 114 & 6,7 & $\mathbf{4 6 5}$ & $\mathbf{2 7 , 1}$ \\
\hline Celkom \% & & $\mathbf{7 5 . 8}$ & & $\mathbf{2 4 . 2}$ & & \\
\hline
\end{tabular}


Výsledky zobrazené $\mathrm{v}$ tabul'ke 8 poukazujú na fakt, že adverbiálne vety sú pomerne rovnomerne zastúpené $v$ jednotlivých typoch textov v skúmanom korpuse. Najvyššia frekvencia určitých adverbiálnych viet bola zaznamenaná v hovorenom prejave, v rozhovoroch, ktoré zároveň obsahovali aj najnižší počet neurčitých adverbiálnych vetných štruktúr. Toto zistenie zase potvrdilo fakt, že určité štruktúry sú znakom neformálnosti, kým neurčité sa častejšie používajú vo formálnom písomnom prejave. Používanie neurčitých tvarov si $\mathrm{v}$ angličtine vyžaduje viac plánovania, ako jednoduché pridanie adverbiálnej vedl'ajšej vety k hlavnej vete. Ked’že hovoriaci nemá pri rozprávaní tol'ko času na plánovanie svojho prejavu ako pri písaní, logicky používa hovorený jazyk menej neurčitých štruktúr. Je zaujímavé, že kým pomer určitých a neurčitých štruktúr $v$ rámci jednotlivých typov vedl'ajších viet je skoro identický, ich zastúpenie v jednotlivých skúmaných textoch sa výrazne líši. Napr. neurčité nominálne vety majú 18-32,\% zastúpenie u vzt'ažných a adverbiálnych viet je rozmedzie iba medzi $2,5-7 \%$.

Čo sa týka frekvenčnej distribúcie funkčných (sémantických) typov adverbiálnych viet, analýzou sme zistili, že používanie časových viet prevyšuje viac ako dvojnásobne frekvenciu používania d'alších najčastejšie použivaných sémantických kategórií adverbiálnych viet a to príčinných, podmienkových a účelových . Vedl'ajšie vety časové sú v skúmanom korpuse charakteristické pre menej formálne texty, ako sú hovorené prejavy a umelecké texty, v ktorých sa použivajú na opis činností a udalostí v súvislosti s inými činnost’ami opísanými v hlavnej vete (Rafajlovičová, 2015).

Tabul'ka 9 Distribúcia sémantických kategórií určitých adverbiálnych viet $\mathbf{v}$ korpuse

\begin{tabular}{|c|c|c|c|c|c|c|}
\hline & $\begin{array}{l}\text { hovorený } \\
\text { prejav }\end{array}$ & $\begin{array}{l}\text { odborné } \\
\text { texty }\end{array}$ & $\begin{array}{l}\text { publicistick } \\
\text { é texty }\end{array}$ & $\begin{array}{l}\text { umelecké } \\
\text { texty }\end{array}$ & $\begin{array}{c}\text { celko } \\
\text { m }\end{array}$ & $\%$ \\
\hline príčina & 92 & 56 & 63 & 62 & 273 & $16 \%$ \\
\hline $\begin{array}{l}\text { porovnani } \\
\text { e }\end{array}$ & 25 & 12 & 22 & 24 & 83 & $4,8 \%$ \\
\hline prípustka & 5 & 27 & 20 & 12 & 64 & $\begin{array}{l}3,7 \\
\%\end{array}$ \\
\hline $\begin{array}{l}\text { podmienk } \\
\text { a }\end{array}$ & 81 & 96 & 58 & 36 & 271 & $\begin{array}{c}15,8 \\
\%\end{array}$ \\
\hline protiklad & 2 & 13 & 13 & 1 & 29 & $1,7 \%$ \\
\hline spôsob & 23 & 10 & 13 & 24 & 70 & $4,2 \%$ \\
\hline miesto & 3 & 4 & 1 & 5 & 13 & $0,8 \%$ \\
\hline proporcia & 1 & 5 & 1 & 2 & 9 & $0,5 \%$ \\
\hline účel & 53 & 75 & 68 & 71 & 267 & $\begin{array}{c}15,5 \\
\%\end{array}$ \\
\hline dôsledok & 3 & 2 & 5 & 10 & 20 & $1,1 \%$ \\
\hline čas & 170 & 103 & 126 & 218 & 617 & $\begin{array}{c}35,9 \\
\%\end{array}$ \\
\hline celkom & 458 & 403 & 390 & 465 & 1716 & \\
\hline$\%$ & $26,7 \%$ & $23,5 \%$ & $22,7 \%$ & $27,1 \%$ & & \\
\hline
\end{tabular}

Sémantické vzt’ahy ako napr. dôsledok, prípustka, protiklad a proporcia sa $\mathrm{v}$ anglickom jazyku vyjadrujú výlučne určitými adverbiálnymi vetami, čo znamená, že tieto tvary adverbiálnych viet sú variabilnejšie ako neurčité. Najfrekventovanejšie sú vedl'ajšie vety časové, ktorých počet $(35.9 \%)$ výrazne prevyšuje iné sémantické kategórie zobrazené v Tabul'ke 9. Určité adverbiálne vety sa v anglickom jazyku

XLinguae, Volume 11, Issue 2, April 2018, ISSN 1337-8384, eISSN 2453-711X 
uvádzajú spojkou, ktorá vel'akrát explicitne vyjadruje sémantický vzt'ah k hlavnej vete, avšak niektoré $z$ nich majú viacnásobný význam, napr. as a since, ktoré vyjadrujú časové, ale aj príčinné súvislosti. Vychádzajúc z faktu, že najčastejšie používané adverbiálne vety sú časové, logicky z toho vyplýva, že najčastejšie používaným spájacím operátorom je spojka vyjadrujúca časové súvislosti. V našom skúmanom korpuse je to spojka when (ked’, kedy) napriek tomu, že angličtina disponuje vel'kým počtom rozmanitých spojok (as, till, until, since, after, before, while, by the time, now that, atd'.), ktoré sa používajú na vyjadrenie časových závislostí. Typickou funkciou časových viet v najbežnejšie používaných typoch textov, t. j. beletrii a ústnom prejave, je uviest' časovú lokalizáciu, vymedzit' zmysel výpovede alebo poskytnút' novú informáciu, ktorá dopĺn̆a význam hlavnej vety (People pre-judge you when you are involved in something like fame Academy.). Ďalšou najfrekventovanejšou podrad'ovacou spojkou je because (ked'že, pretože), ktorá vyjadruje kauzálny vzt’ah. Táto spojka sa najčastejšie používa v hovorenom prejave, kde hovoriaci používajú na vysvetlenie svojich činov, myšlienok a názorov množstvo kauzálnych zdôvodnení. Kým because môžeme nájst' skôr v menej formálnych textoch, spojka since, ktorá je významovo identická, je charakteristická pre formálny jazykový prejav $\mathrm{v}$ odborných textoch.

Z celkového počtu 414 neurčitých štruktúr (to-infinitive, ing-, -ed participle) je 64,5\% vyjadrených neurčitkom (to-infinitive). Najväčšie zastúpenie majú v písaných textoch a najmenej sa používajú $v$ hovorenom prejave. Graf 4 zobrazuje najčastejšie vyjadrované sémantické funkcie jednotlivými neurčitými tvarmi v skúmanom korpuse.

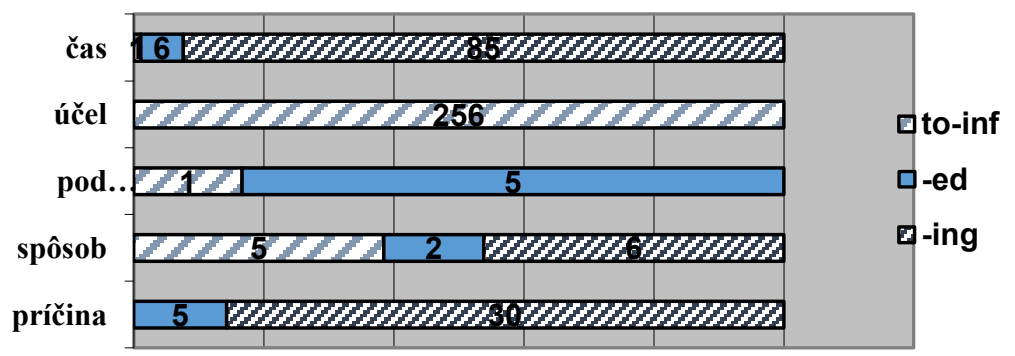

Graf 4 Distribúcia neurčitých štruktúr v rámci sémantických kategórií Neurčitok (to-infinitive), sa v angličtine najčastejšie používa na vyjadrenie účelu ( $I$ returned to the kitchen to mix a second drink and sat with it at the kitchen table.). Neurčitkové vety sa najčastejšie nachádzajú v odborných textoch opisujúcich určité pracovné postupy, a práve neurčitou infinitívnou vedl'ajšou vetou sú následne vyjadrené odporúčania pre d’alšie vylepšenie v budúcnosti, ako napr. (The government has taken on a major preventative scheme, introducing the 5+ a day dietary standard to improve the intake of more fruits and vegetables into people's daily diets.). Neurčité participiálne vety (-ing, ed-participle) sa najčastejšie používajú na vyjadrenie časových súvislostí a príčinných okolností (Some others are overly worried, having parents who have O.C.D., also having an irregular metabolism, or an abnormal antibody response to a virus.). Neurčité adverbiálne vety sa zvyčajne nachádzajú vo finálnej pozícii, t.j. nasledujú za hlavnou vetou, avšak časové, ktoré označujú sprievodné deje počas ktorých sa odohráva dej hlavnej vety, môžeme nájst' aj $\mathrm{v}$ iniciálnej pozícii pred hlavnou vetou (Hanging a few feet above the Chilterns escarpment, our crew enacted morality's ancient, irresolvable dilemma: us, or me).

Jedným z dôležitých ukazovatel'ov funkčnej analýzy adverbiálnych viet je aj ich pozícia vzhl'adom k hlavnej vete. Biber (1999:837) zistil, že jedným z činitel'ov 
ovplyvňujúcich pozíciu adverbiálnych viet, je ich dížka. Kvôli l’ahšiemu spracovaniu informácie $\mathrm{v}$ anglickom jazyku dávajú v súvetí dlhé, komplexné štruktúry prednost' postaveniu za hlavnou vetou, avšak Greenbaum a Nelson (1996) tvrdia, že na pozíciu niektorých typov adverbiálnych viet nevplýva ich dížka. Podl'a Verstraete (2006), iniciálne postavenie hrá dôležitú úlohu pri organizácii diskurzu a slúži ako diskurzívny „most“ medzi predchádzajúcou a nasledujúcou výpoved’ou, kým finálne postavenie má vymedzujúcu funkciu, má špecifikovat' okolnosti deja, udalosti alebo javu vyjadreného v hlavnej vete. Na základe našej analýzy postavenia adverbiálnych viet môžeme konštatovat', že vo všeobecnosti uprednostňujú adverbiálne vedl'ajšie vety finálnu pozíciu, t.j. postavenie za hlavnou vetou. Frekvencia výskytu adverbiálnych viet $\mathrm{v}$ tejto pozícii je viac ako dvojnásobne vyššia ako frekvencia adverbiálnych viet pred hlavnou vetou, v iniciálnej pozícii (Tabul'ka 10).

Tabul'ka 10 Pozícia určitých adverbiálnych viet $\mathrm{v}$ rámci textov v skúmanom korpuse

\begin{tabular}{|l|c|c|c|c|}
\hline \multicolumn{1}{|c|}{ typ textu } & $\begin{array}{c}\text { INICIÁLNA } \\
\text { pozícia }\end{array}$ & $\begin{array}{c}\text { FINÁLNA } \\
\text { pozícia }\end{array}$ & $\begin{array}{c}\text { bez hlavnej } \\
\text { vety }\end{array}$ & celkom \\
\hline hovorené prejavy & 123 & 248 & 13 & $\mathbf{3 8 4}$ \\
\hline odborné texty & 113 & 177 & 1 & $\mathbf{2 9 1}$ \\
\hline publicistické texty & 73 & 202 & 1 & $\mathbf{2 7 6}$ \\
\hline umelecké texty & 100 & 250 & 1 & $\mathbf{3 5 1}$ \\
\hline \multicolumn{1}{|c|}{ Celkom } & $\mathbf{4 0 9}$ & $\mathbf{8 7 7}$ & $\mathbf{1 6}$ & $\mathbf{1 3 0 2}$ \\
\hline
\end{tabular}

Pomer medzi iniciálnou a finálnou pozíciou adverbiálnych viet sa líši v rámci skúmaných textov a aj v rámci jednotlivých sémantických typov viet. Najviac adverbiálnych viet vo finálnej pozícii sa nachádza v hovorených prejavoch a umeleckých textoch, ktoré v našom výskume považujeme za menej formálne v porovnaní s publicistickými a odbornými textami. Kým adverbiálne vedl'ajšie vety času, príčiny a spôsobu výrazne preferujú finálnu pozíciu vhovorenom aj $\mathrm{v}$ písomnom prejave, distribúcia ostatných funkčných kategórií adverbiálnych viet v skúmaných médiách je úplne odlišná. Príčinné vzt’ahy vyjadrené spojkou because sú menej plánované ako iné vzt’ahy, $\mathrm{v}$ dôsledku čoho sa vedl'ajšie vety uvádzané touto spojkou používajú na doplnenie hlavnej vety dodatočným vysvetlením alebo zdôvodnením, preto ich v prevažnej miere nachádzame vo finálnej pozícii (In intensive care I had already noticed that I could see through people because my brain was very raw.). Naopak podmienkové vety vykazujú v rozhovoroch miernu preferenciu iniciálneho postavenia, kde vytvárajú spojenie s predchádzajúcou výpoved'ou a vymedzujú, resp. kvalifikujú interpretáciu hlavnej vety (If he had not thought to tell me that story, I would not have had that beginning.). V publicistických textoch a umeleckých textoch je ich distribúcia rovnomerná, avšak v odborných textoch sa častejšie nachádzajú za hlavnou vetou, kde dopínajú informáciu sprostredkovanú hlavnou vetou. Na základe výsledkov predchádzajúcich výskumov vychádzajúcich $\mathrm{z}$ národných korpusov a nášho korpusu sme dospeli $\mathrm{k}$ názoru, že postavenie adverbiálnych viet vzhl'adom $\mathrm{k}$ hlavnej vete je ovplyvňované nielen dížkou vedl’ajšej vety, ale predovšetkým jej funkciou vo výpovedi a tým, či je použitá $\mathrm{v}$ hovorenom alebo písomnom prejave.

\section{Záver}

Predložená práca sa venuje problematike subordinácie $\mathrm{v}$ anglických textoch $\mathrm{v}$ rámci jednotlivých štýlov (odborné texty, umelecké texty, publicistické texty, hovorené prejavy) ústneho a písomného prejavu. Kvantitatívny a kvalitatívny výskum sa 
zakladá na analýze materiálu získaného z vlastného korpusu menšieho rozsahu zostaveného $\mathrm{z}$ prepisov rozhovorov, novinových článkov, kapitol $\mathrm{z}$ beletrie a odborných článkov. Výskum je zameraný na distribúciu jednotlivých typov vedl'ajších viet podl'a v súčasnosti dominujúcich klasifikácií (určité a neurčité, nominálne, adverbiálne, relatívne) nielen na základe ich štrukturálnych a sémantických charakteristík, ale následne aj z hl’adiska funkčných aspektov. V súlade so súčasnými trendmi v lingvistike sa po analýze štrukturálnych charakteristík odpútavame od formy, hlavný dôraz kladieme na funkčné aspekty a uvádzame do súvislosti dané formy s ich funkčnými charakteristikami v rôznych typoch textov a prehovorov. Práca je založená na detailnom opise a charakteristike jednotlivých typov vedl'ajších viet a porovnaní ich distribúcie v textoch, ich vetoslednej realizácii, ako aj charakteristike diskurzívnych funkcií, ktoré v textoch plnia.

Hlavných ciel'om práce bolo zistit', či odlišné typy textov využívajú odlišné formálne a funkčné typy podrad'ovacích viet, ktoré typy vedl'ajších viet sú charakteristické pre konkrétny text a či možno vymedzit' vzorce typické pre distribúciu vedl'ajších viet v hovorenom a písanom prejave. Funkčná analýza troch centrálnych typov vedl'ajších viet zastúpených $\mathrm{v}$ korpuse poukázala, že distribúcia formálnych a funkčných typov vedl'ajších viet sa odlišuje $\mathrm{v}$ jednotlivých typoch skúmaných textov. Na základe výsledkov sme dospeli k zaujímavým zisteniam o ich diskurzívnych funkciách.

V hovorených prejavoch sú najviac zastúpené nominálne vedl'ajšie vety $(33,7 \%)$ a v menšej miere vzt'ažné vety. Môžeme si to vysvetlit' tým, že v ústnej komunikácii zúčastnení najviac rozprávajú o sebe, vyjadrujú svoje postoje, hovoria o svojich názoroch, stanoviskách a pocitoch, resp. sprostredkúvajú získané informácie. Pre tento typ interakcie je typické používanie širokého rozsahu performatívnych slovies, ako napríklad (suggest, advice, state), slovies zmyslového vnímania (think, know, hope), slov vyjadrujúcich psychický stav (I'm happy, glad, lucky, sad, sorry), postoje (I' $m$ shocked, worried), alebo opisujúcich podstatu nejakého problému (problem, trouble, feeling, hope, reason), za ktorými v angličtine nasledujú nominálne vety. $\mathrm{V}$ rozhovoroch sa interakcia medzi zúčastnenými zvyčajne týka udalostí v určitom čase a na určitom mieste a hovoriaci taktiež vyjadrujú kauzálne vzt’ahy, alebo prezentujú situácie s možnými dôsledkami. Na vyjadrenie týchto sémantických vzt’ahov sa v skúmaných rozhovoroch najčastejšie používajú časové, príčinné a podmienkové vety, čo vysvetl'uje dôvod, prečo práve tieto funkčné typy vedl'ajších viet sú najviac zastúpené práve v hovorených prejavoch. Pre hovorené prejavy skúmané $\mathrm{v}$ rámci nášho korpusu je príznačné najvyššie percentuálne zastúpenie (35,3\%) určitých vedl'ajších viet (finite clauses), a naopak najnižší výskyt neurčitých vedl'ajších viet (non-finite clauses).

Tak ako v hovorených prejavoch, aj v odborných textoch najvyššiu frekvenciu výskytu majú nominálne vedl'ajšie vety $(24,6 \%)$. Funkcia nominálnych viet v odborných textoch je však odlišná. V tomto type jazykového prejavu ich pisatelia najčastejšie použivajú na prezentáciu argumentov podporujúcich rôzne teórie a na vyjadrenie svojich postojov vo vzt’ahu k diskutovanej problematike v rámci odboru. Preto sa v prevažnej miere používajú po slovesách see, believe, assume, suppose, show, mean, conclude a suggest. Druhým najčastejšie používaným typom vedl'ajších viet $\mathrm{v}$ tomto type textov sú vzt'ažné vety $(23,9 \%)$. V odbornej literatúre sa v prevažnej väčšine používajú neurčité vzt'ažné vedl'ajšie vety, ktoré poskytujú doplňujúcu informáciu o procedúrach a postupoch, resp. vysvetl'ujú odbornú terminológiu. Adverbiálne vedl'ajšie vety v porovnaní s ostatnými typmi vedl'ajších viet sú najmenej zastúpené v odborných článkoch, vyskytujú sa tu najmä podmienkové, účelové, príčinné a prípustkové vedl'ajšie vety, ktoré sa používajú na popis procedúr, špecifikujú podmienky a rozvíjajú argumenty, čo je príznačné pre tento typ písaného prejavu. 
V publicistických textoch naopak, najvyššie zastúpenie v porovnaní s ostatnými funkčnými typmi majú vedl'ajšie vety vzt’ažné $(24,6 \%)$. Post modifikácia životných a neživotných substantív je tu realizovaná pomocou určitých aj neurčitých tvarov. Vd’aka vysokému počtu vlastných mien v publicistických textoch, v porovnaní s ostatnými textami sa tu najčastejšie používajú nereštriktívne vzt'ažné vety. Preferované používanie neurčitých vedl'ajších viet $\mathrm{v}$ publicistickom štýle možno pripísat' tendencii $\mathrm{k}$ „hospodárnosti“ vyjadrovania sa a poskytovaniu kompaktných informácií. Zastúpenie nominálnych vedlajších viet je $\mathrm{v}$ tomto type textov nižšie ako u horeuvedených typoch textov. V publicistickom štýle sa nominálne vety najviac používajú po slovesách vyjadrujúcich stav poznania (believe, realize), po komunikačných slovesách (admit, agree, announce, confirm, deny, inform) a po slovese „mysliet'“ v minulom čase (thought), ked’že tieto texty v drvivej väčšine oznamujú minulé udalosti. Čo sa týka adverbiálnych vedl'ajších viet, v publicistických textoch sú najčastejšie používané časové, účelové, príčinné a podmienkové vedl'ajšie vety. Účely vyjadrujúce motiváciu k udalostiam opisovaným v textoch sú realizované vo prevažnej väčšine neurčitkovými vedl'ajšími vetami.

V porovnaní s horeuvedenými typmi textov je distribúcia funkčných typov vedlajších viet najvyváženejšia $\mathrm{v}$ umeleckých textoch. Najvyššie percentuálne zastúpenie tu majú vedl'ajšie vety adverbiálne $(27,1 \%)$, čo je zároveň najvyššie percento všetkých adverbiálnych viet $\mathrm{v}$ celom skúmanom korpuse. Medzi najbežnejšie používané sémantické typy adverbiálnych viet $\mathrm{v}$ týchto textoch patria vety časové, účelové a príčinné. Častejšie ako v ostatných skúmaných typoch textov sa tu používajú aj iné vety, ktoré poskytujú doplňujúce informácie, resp. popisy činností, stavov, alebo udalostí vyjadrených v hlavnej vete. Aj napriek tomu, že percento ich výskytu nie je vysoké, vedl'ajšie vety spôsobové, sprostredkujúce detaily o činnostiach, sú bežnejšie $\mathrm{v}$ umeleckých textoch ako v ostatných. Čo sa týka pozície adverbiálnych viet, najčastejšie sa nachádzajú vo finálnej pozícii za hlavnou vetou, a to hlavne vo vetách vyjadrujúcich temporálne vzt'ahy. Frekvencia používania vzt'ažných viet je v tomto type textov porovnatel'ná s výskytom vzt'ažných viet v hovorených prejavoch, aj ked' sme tu zaznamenali odlišnosti v používaní spájacích operátorov, čiže „relatív“ (pozri graf 3).

Výsledky ukázali, že najčastejšie používaným typom vedl'ajších viet v korpuse sú nominálne vety s frekvenciou výskytu $39 \%$. Naopak, adverbiálne vety majú celkove najnižšiu frekvenciu výskytu. V najpočetnejšom zastúpení sa nachádzajú $\mathrm{v}$ umeleckých textoch a hovorených prejavoch. Relatívne vety sú najrovnomernejšie rozdelené vo všetkých typoch textov s najvyššou frekvenciou v umeleckých textoch. Rozdiely v použivaní relatív môžeme pripísat' rozdielnej povahe jednotlivých textov (v novinových článkoch sa nachádza vel'ké množstvo vlastných podstatných mien, ktoré nevyžadujú bližšiu identifikáciu formou reštriktívnych viet), kým v odbornej literatúre sa v prevažnej väčšine použivajú neurčité relatívne vedlajšie vety, ktoré poskytujú doplňujúcu informáciu o procedúrach a postupoch a vysvetlujú odbornú terminológiu.

Zastúpenie určitých vedl'ajších viet (finite clauses) poukazuje na vzostupnú tendenciu, počnúc od najnižšieho počtu $\mathrm{v}$ odbornom štýle, považovanom za najformálnejší jazykový prejav zo skupiny skúmaných textov, až po najvyšší počet ich výskytu v rozhovoroch, ktoré sme označili za najmenej formálny prejav. Čo sa týka distribúcie neurčitých vedl'ajších viet (non-finite clauses), tie sú naopak najčastejšie používané $\mathrm{v}$ odborných textoch a najmenej $\mathrm{v}$ ústnom prejave. Na základe týchto výsledkov sme 
došli k záveru, že k určitým lingvistickým vlastnostiam môžeme priradit' hodnoty stratégií na úrovni formálnosti jazykového štýlu, t. j. určité vedl'ajšie vety môžeme považovat' za indikátor neformálnych jazykových prejavov, kým neurčité vedlajšie vety sú charakteristické pre formálny písomný prejav. Na základe výsledkov analýz jednotlivých textov $\mathrm{z}$ hladiska sme zistili, že rozdiely $\mathrm{v}$ distribúcii jednotlivých funkčných a formálnych typov vedl'ajších viet nepramenia z rozdielu, či je jazykový prejav hovorený alebo písomný, ale zo samotnej podstaty textu a úrovne jeho formálnosti.

$\mathrm{Na}$ záver môžeme stručne zhrnút, že variácia v lingvistickom prejave je determinovaná vol'bami uskutočnenými hovoriacim, resp. pisatel'om diskurzu, ktoré môžu vyústit' do rôznych činitel'ov ovplyvňujúcich prehovor. Výber syntaktických stratégií sa môže líšit' v každom zo skúmaných typov textov, čo sa dá zistit' iba ak skúmame gramatické popisy vel'kého množstva porovnatel'ných dát získaných $\mathrm{z}$ jazykového materiálu.

\section{Bibliographic references}

BEAMAN, K. 1984. Coordination and subordination revisited: Syntactic complexity in spoken and written narrative discourse. In Deborah Tannen (ed), Coherence in spoken and written discourse. 45-80. New Jersey: ABLEX.

BIBER, D. et al. 1999. Longman Grammar of Spoken and Written English. Pearson Education Limited. ISBN 0-582-237254

BIBER, D. et al. 1998. Corpus Linguistics. Cambridge University Press, ISBN 0-52149957-7

CRISTOFARO, S. 2005. Subordination. Oxford. Oxford University Press..ISBN 9780-1992-8200-5

CARTER, R., - McCARTHY, M. 2006. Cambridge grammar of English: a comprehensive guide Cambridge: Cambridge University Press.

CHAFE, W. - DANIELWICZ, J. 1987. Properties of Spoken and Written Language.

Technical Report 5 , Available online: http://www.eric.ed.gov/contentdelivery/servlet/ERICServlet?accno=ED282230 [cit.25 .10.2017]

CRYSTAL, D. 1997. The Cambridge Encyclopaedia of the English Language $\left(2^{\text {nd }}\right.$ edition). Cambridge University Press, ISBN 0-521-53033-4

DIESSEL, H. - HETTERLE, K. 2011. Causal clauses: A cross-linguistic investigation of their structure, meaning, and use. In: Peter Siemund (ed.), Linguistic Universals and Language Variation, 21-52. Berlin: Mouton de Gruyter. , Available online: http://www.personal.uni-jena.de [cit. 18.10.2017]

DIK, S. C. 1978. Functional Grammar, London: Academic press

DRIEMAN, G. H. J. 1962. Differences between written and spoken language. In: Acta Psychologica 20, 36-57.

GIVÓN, T. 2008. The ontogeny of relative clauses: How children learn to negotiate complex reference. In the Genesis of Syntactic Complexity, T. Givón, Ch. 8. Amsterdam. John Benjamins.

GREENBAUM, S. - NELSON, G. 1995. Clause relationships in spoken and written English. In: Functions of Language Volume 2, Number 1, pp. 1-21.

HAIMAN. J. - THOMPSON, S. 1988. Clause Combining in Grammar and Discourse. Cambridge. CUP. Reviewed work In: Journal of Linguistics. Vol. 26, No. 2 (Sep. 1990), pp. 505-509

HALLIDAY, M. A. K.1989. Spoken and Written Language. Oxford: Oxford University Press.

HANSEN. C. F. - RAMM. W. 2008. Subordination versus Coordination in Sentence and Text. eBook. John Benjamins Publishing Company. ISBN 978-9-0272-9031-1 
HUDSON-ETTLE, D., M. 1998. Grammatical Subordination Strategies in Differing Text Types in the English Spoken and Written in Kenya. , Available online: http://www.tu-chemnitz.de/phil/english/chairs/linguist/ [cit.30.09.2017]

McCARTHY, M. - CARTER, R. 1995. Spoken grammar: what is it and how can we teach it? ELT Journal, 49 (3), 207-218.

McCARTHY, M. 1998. Spoken language and applied linguistics. Cambridge:

Cambridge University Press.

LAURY, R. - SUZUKI, R. 2011. Subordination in Conversation. Amsterdam. John

Benjamins. ISBN 978-9-0272-2634-1

LOCK, G. 1997. Functional English Grammar. Cambridge University Press. ISBN 0521-45922-2

QUIRK, R. et al. 1985. A Comprehensive Grammar of the English Language. Longman Group UK Limited. ISBN 0-582-51734-6

RAFAJLOVICOVA, R. 2011. Dependent Clauses, their occurrence and role in different text types. In: English Matters II. A collection of papers by the Institute of British and American Studies, FF PU Prešov, Slovakia. ISBN 978-80-555-0439-1

RAFAJLOVICOVA, R. 2013. Subordination in Different Text Types. Presov. FF PU. ISBN 978-80-555-1047-7

RAFAJLOVICOVA, R. 2015. Subordinácia vanglickom ústnom a písomnom prejave. Ecoletra.com - Scientific eJournal, Vol. 1, 2015/ 01, ISSN 2377-9848, pp. $120-131$

SIEWIERSKA, A. 1991. Functional Grammar. Routledge, London. ISBN 0-41502645-8

TANNEN, D. 1982. Oral and Literate Strategies in Spoken and Written Narratives. In: Language.Vol. 58, No. 1 (Mar., 1982), pp. 1-21 Published by: Linguistic Society of America Article Stable URL: http://www.jstor.org/stable/413530

THOMPSON, S. 1984. Subordination' in Formal and Informal Discourse. In Deborah Schiffrin, ed., Meaning, Form, and Use in Context: Linguistic Applications (Georgetown University Round Table on Languages and Linguistics), Georgetown: Georgetown University Press, 85-94.

Words: 8856

Characters: 63788 (35,44 standard pages)

Doc. PhDr. Rita Rafajlovicova, PhD.

Institute of British and American studies

Faculty of Arts

Presov University

ul. 17. novembra 1, 08078 Presov

Slovakia

rita.rafajlovicova@unipo.sk

XLinguae, Volume 11, Issue 2, April 2018, ISSN 1337-8384, eISSN 2453-711X 